\title{
Retention in guinea pigs of monocular pattern discriminations during reversal acquisition with the opposite eye'
}

\author{
DANIEL M. LEVINSON 2 AND CHARLES L. SHERIDAN \\ UNIVERSITY OF MISSOURI AT KANSAS CITY AND VA HOSPITAL, KANSAS CITY, MISSOURI
}

\begin{abstract}
Although veridical interocular transfer occurs in guinea pigs, $S s$ in the present study retained monocular patter discriminations while leaming the reverse discrimination with the opposite eye.
\end{abstract}

Albino rats retain pattern discriminations made with one eye while learning the reverse discrimination with the opposite eye (Sheridan, 1965a). This would seem to indicate the absence of interocular transfer, but the dissociation takes place when the discrimination problem is one which shows considerable interocular transfer (Sheridan, 1965a; Creel \& Sheridan, 1966). In the experiment reported here an attempt was made to evaluate the generality of the albino rat interocular dissociation phenomenon by measuring retention of "conflicting" discriminations mediated by opposite eyes in another rodent-the guinea pig. Guinea pigs are particularly interesting Ss for this sort of experiment because they are capable of perfect interocular transfer provided they are more than a few weeks old at the time of training (Petre \& Sheridan, 1966).

\section{Subjects}

The Ss were four experimentally naive, adult, male guinea pigs, one albino and three with pigmented eyes. Apparatus

The apparatus, a Thompson-Bryant (1955) box, utilized shock motivation and consisted of a start box, runway, choice-point with two alternative entryways, and a goalbox.

\section{Procedure}

Ss were pretrained to run to the goalbox and to knock over gray stimulus cards which blocked the goalbox entryways. One eye was then covered with an opaque contact occluder, and Ss were trained to choose a door covered with half-inch horizontal stripes in preference to one covered with similar vertical stripes. Training continued until a criterion of 18 correct responses in 20 consecutive trials was met, then further training was given until $S$ made an additional 10 consecutive correct responses. Next, the occluder was shifted to the opposite eye, and reversal training $(\mathrm{V}+, \mathrm{H}-)$ was carried out on the "naive" eye. Having reached criterion on the "naive"-eye reversal task, $\mathbf{S}$ was tested on the originally trained eye for retention of the original discrimination.

After completion of training and testing on the horizontal-vertical discrimination, each $\mathrm{S}$ was required to discriminate an upright from an inverted triangle, the procedure being the same as that just described for the horizontal-vertical discriminations.

\section{Results}

Horizontal-Vertical Discrimination. Although the original discrimination transferred veridically to the naive eye, the naive-eye reversal problem did not interfere with retention of the original discrimination. Table 1 shows that acquisition of the reversal discrimination with the naive eye took many more trials than had original learning (Column 1 vs. Column 2) and that the original discrimination intruded on the naive-eye reversal discrimination (Column 3 vs. Column 4). That the retarded second-eye performance was due to interference from the original discrimination and not to any initial preference for the horizontal cue may be seen from the fact that $\mathrm{Ss}$, when naive, responded at chance levels (see Column 3). When, after second-eye reversal training, Ss were given 10 retention trials on the original discrimination via the originally trained eye, three Ss performed immediately at the $90 \%$ correct level. One pigmented S chose the originally correct cue only $60 \%$ of the time during the first 10 trials, but made $90 \%$ correct responses in a second 10-trial block.

Ipright vs. Inverted Triangle Discrimination. The measures of veridical interocular transfer employed on the horizontal-vertical discrimination did not appear meaningful when applied to the upright vs. inverted triangle, since Ss seemed to respond to the horizontal and (approximately) vertical components of the triangles. One $\mathrm{S}$ became ill and was eliminated from the group during this problem. After original monocular training with the upright stimulus correct and subsequent reversal training on the second eye, Ss were retested on the original eye for retention of the original problem. The albino $S$ and one of the pigmented Ss performed at the $90 \%$ level during the

Table 1. Summary of interocular interaction measures for all subjects on the horizontal-vertical discrimination.

\begin{tabular}{lccccc} 
& Trials to Criterion & \multicolumn{2}{c}{$\begin{array}{c}\text { Percentage Correct } \\
\text { (First 10 Trials) }\end{array}$} & $\begin{array}{c}\text { Percentage Correct } \\
\text { Original Eye Test }\end{array}$ \\
& 1st eye & 2nd eye & $\begin{array}{c}\text { 1st eye } \\
\text { 2nd eye }\end{array}$ \\
\cline { 2 - 6 } P1 & 60 & 328 & 50 & 20 & 90 \\
P2 & 57 & 112 & 40 & 10 & $60(90$ on 2nd 10) \\
P3 & 62 & 275 & 40 & 10 & 90 \\
A1 & 50 & 92 & 50 & 40 & 20 \\
\hline
\end{tabular}


first 10 retest trials. The remaining animal had performed at the $60 \%$ level on the horizontal-vertical retest, and also performed at the $60 \%$ level on the triangle problem. In this case, he did not reach the $90 \%$ level until the fourth 10-trial block of retesting. Discussion

Guinea pigs, like albino rats, show a dissociation of conflicting discriminations mediated by opposite eyes under conditions which originally give rise to veridical interocular transfer. Since guinea pigs have a substantial band of uncrossed optic fibers (Hess, 1958), there is direct input from each eye to both hemispheres. Thus, it seems clear that the interocular interactions reported here cannot be due to dominance of "direct" (optic pathway) over "indirect" (commissural) inputs, though such an interpretation is able to account for a very similar phenomenon in chiasma-sectioned cats (Myers, 1962).

Limitations in information transmission via optic pathways and commissural fiber bundles seem to play an important role in interocular transfer in rodents under some conditions (Bianki, 1959; Sheridan, $1965 \mathrm{~b})$ but it may be that the discriminative stimulus properties of occluders make an especially large contribution to conflicting discrimination performances. On the basis of present data, it is not possible to provide a clear evaluation of the contribution made by these two factors in determining "conflicting" discrimination performances.

\section{References}

Bianki, V. L. The role of the corpus callosum in paired activity of the optical and cutaneous analyzers in the rabbit. Pavlov. J. higher nerv. Act., 1959, 9, 110-120.

Creel, D. J., \& Sheridan, C. L. Monocular acquisition and interocular transfer in albino rats with unilateral striate ablations. Psychon. Sci., 1966, 6, 89-90.

Hess, A. Optic centers and pathways after eye removal in fetal guinea pigs. $J$. comp. Neurol., 1958, 109, 91-116.

Myers, R. E. Transmission of visual information within and between the hemispheres: a behavioral study. In V. B. Mountcastle Interhemispheric relations and cerebral dominance. Baltimore: The Johns Hopkins Press, 1962.

Petre, C. C., \& Sheridan, C. L. Interocular transfer in albino and Pigmented perinatal guinea pigs. Psychon. Sci., 1966, 6, 215-216.

Sheridan, C. L. Interocular interaction of conflicting discrimination habits in the albino rat: A preliminary report. Psychon. Sci., $1965,3,303-304$.

Sheridan, C. L. Interocular transfer of brightness and pattern discriminations in normal and corpus callosum-sectioned rats. $J$. comp. physiol. Psychol., 1965, 59, 292-294.

Thompson, R., \& Bryant, H. Memory as affected by activity of the relevant receptor. Psychol. Rep., 1955, 1, 393-400.

\section{Notes}

1. This study was supported in part by 8200 (Research) funds from the Veterans Administration and in part by Grant MH-12268-01 from the Public Health Service to Charles L. Sheridan.

2. Now at the University of Southern California. 